\title{
Starvation resistance of gypsy moth, Lymantria dispar (L.) (Lepidoptera: Lymantriidae): tradeoffs among growth, body size, and survival
}

\author{
Brian A. Stockhoff \\ Department of Biology, University of Michigan, Ann Arbor, MI 48109-1048, USA
}

Received February 11, 1991 / Accepted in revised form July 5, 1991

Summary. Survival and body composition of starving gypsy moth larvae initially reared on aspen foliage or artificial diet differing in nitrogen $(\mathrm{N})$ and carbohydrate concentration were examined under laboratory conditions. Diet nitrogen concentration strongly affected starvation resistance and body composition, but diet carbohydrate content had no effects on these. Within any single diet treatment, greater body mass afforded greater resistance to starvation. However, starving larvae reared on $1.5 \% \mathrm{~N}$ diet survived nearly three days longer than larvae reared on $3.5 \% \mathrm{~N}$ diet. Larvae reared on artificial diet survived longer than larvae reared on aspen. Differences in survival of larvae reared on artificial diet with low and high nitrogen concentrations could not be attributed to variation in respiration rates, but were associated with differences in body composition. Although percentage lipid in larvae was unaffected by diet nitrogen concentration, larvae reared on $1.5 \% \mathrm{~N}$ diet had a higher percentage carbohydrate and lower percentage protein in their bodies prior to starvation than larvae reared on $3.5 \% \mathrm{~N}$ diet. Hence, larger energy reserves of larvae reared on low nitrogen diet may have contributed to their greater starvation resistance. Whereas survival under food stress was lower for larvae reared on high $\mathrm{N}$ diets, growth rates and pupal weights were higher, suggesting a tradeoff between rapid growth and survival. Larger body size does not necessarily reflect larger energy reserves, and, in fact, larger body size accrued via greater protein accumulation may be at the expense of energy reserves. Large, fast-growing larvae may be more fit when food is abundant, but this advantage may be severely diminished under food stress. The potential ecological and evolutionary implications of a growth/ survival tradeoff are discussed.

Key words: Lymantria dispar - Starvation - Fitness tradeoff - Nitrogen - Survival
Studies of insect nutritional ecology typically examine the effects of food consumption and utilization on fitness parameters such as growth and survival. However, resistance to food deprivation is also likely to be an important fitness attribute in juvenile, flightless insects such as Lepidopteran larvae. Because of changes in food quality or preference, falling from the host plant, food depletion, etc., an insect may need to travel between host plants. Host location is potentially a lengthy process for Lepidopteran larvae with limited mobility, and starvation can occur before a suitable host plant is found. The gypsy moth, Lymantria dispar (L.) (Lepidoptera: Lymantriidae), is an insect pest that occurs in large outbreaks and commonly defoliates entire forests. Under severe defoliation, individuals may be forced to wander extensively to locate other hosts. Even if food stress is a relatively rare event, its occurrence could impose strong selective pressure for traits conferring starvation resistance.

Although death by starvation is undoubtedly a complex physiological process, depletion of reserves used in energy metabolism plays a major role. Because utilization of carbohydrates, lipids, and proteins results in different net energy yields, individuals with different ratios of these in their tissues would be expected to survive different lengths of time. Diet history can substantially affect body composition (Lii et al. 1975; Karowe and Martin 1989), so that previous diet may directly affect survival time of starving insects. Because lipids and carbohydrates are more readily accessible as energy sources than is protein, diets leading to larger lipid or carbohydrate stores and high lipid:protein or carbohydrate:protein ratios in the body would be expected to yield the longest survival times under starvation conditions.

Starvation resistance also tends to increase with body size, despite the greater absolute energy requirements of large individuals. Because relative metabolic rate scales inversely with body mass, less energy is expended for 
each additional unit of body mass. As a result, large organisms are postulated to survive longer under starvation conditions than small organisms (Peters 1983), given identical percentages of body mass as energy reserves.

There are few studies of poikilotherm starvation as a function of diet or body size (but see Threlkeld 1976; Goulden and Hornig 1980). Numerous investigators have examined hormonal and enzymatic changes in insects during fasting and starvation (Cymborowski et al. 1982; Lohr and Gade 1983; Saleem and Shakoori 1985; Siegert and Ziegler 1983; Siegert 1987, 1988). Starvation effects on oxygen consumption (Jalees and Murad 1974; Singhal and Vats 1976), food utilization (Hill and Goldsworthy 1970; Schroeder 1976; Singhal and Vats 1976), hemolymph composition (Milstead 1967; Dahlman 1973; Mwangi and Goldsworthy 1977; Woodring 1984), and duration of life (Pearl and Parker 1924; Gerber 1984) have also been examined. Kopec (1924) and Leonard (1970) have assessed the effects of partial starvation on larval development of gypsy moth. However, no studies explicitly test relations among body size, body composition, diet, and starvation resistance in an herbivorous insect.

In this study I examined relations among body mass, body composition, respiration rates, and survival time of starving gypsy moth larvae previously reared on diets differing in protein and carbohydrate content.

\section{Materials and methods}

\section{Insects and diet treatments}

Egg masses of gypsy moth were collected in April 1990 from a newly infested forest in Roscommon Co., Michigan, USA. Eggs were surface-sterilized in a $3.7 \%$ formalin solution for $1 \mathrm{~h}$ and then rinsed in running tap water for $1 \mathrm{~h}$. Following drying under a fume hood, individual egg masses were placed in $100-\mathrm{mm}$ plastic petri dishes for hatching. Eggs and larvae were incubated at $25^{\circ} \mathrm{C}$ with a $16 \mathrm{~h}$ light $-8 \mathrm{~h}$ dark cycle. Upon hatching, larvae were placed individually into $30-\mathrm{ml}$ plastic cups at approximately $75 \%$ relative humidity.

Four artificial diets were prepared to test the effects of dietary protein and starch on starvation resistance. Common to all diets was the following mixture (for 1.01 of diet): stabilized wheat germ (30.6 g), ascorbic acid (5.5 g), p-hydroxybenzoic acid methyl ester $(1.2 \mathrm{~g})$, Beck's insect salt mix ( $7.8 \mathrm{~g})$, sorbic acid (2.2 g), dextrose ( $3.3 \mathrm{~g})$, choline chloride $(0.6 \mathrm{~g})$, BioServ Lepidoptera vitamin mix $(0.7 \mathrm{~g}$ dissolved in $2 \mathrm{ml}$ water $)$, and linseed oil $(8 \mathrm{~g})$. Two concentrations of protein and carbohydrate were established, and all four possible combinations of these tested. Low and high protein diets contained $4 \mathrm{~g}$ and $32 \mathrm{~g}$ of casein $/ 1$, respectively. Combined with the wheat germ (containing $25 \%$ protein), these diets contained approximately $1.5 \% \mathrm{~N}$ and $3.5 \% \mathrm{~N}(\mathrm{dw})$. Low and high carbohydrate diets contained 0 and $25 \mathrm{~g}$ of soluble potato starch/l, respectively. The low carbohydrate diet was not carbohydrate-free as it contained dextrose and wheat germ. Alpha-cellulose was added to each diet as needed to bring the total dry components to $168 \mathrm{~g} / \mathrm{l}$. Oil, vitamins and dry components were combined with a boiled mixture of $25 \mathrm{~g}$ of agar and $805 \mathrm{ml}$ of deionized, distilled water to make 11 of diet. For comparison, the Bell diet commonly used for gypsy moth contains $120 \mathrm{~g}$ of wheat germ and $25 \mathrm{~g}$ of casein per liter of finished diet (Odell et al. 1985). Growth on the 3.5\% N diet is similar to that on the Bell diet (female pupal dry mass $=321 \mathrm{mg}$, neonate to pupa developmental period $=32 \mathrm{~d}$ ) whereas growth on the $1.5 \% \mathrm{~N}$ diet is much reduced (female pupal dry mass $=157 \mathrm{mg}$, neonate to pupa developmental period $=34 \mathrm{~d}$ ) (Stockhoff, unpub. data).

To determine the starvation resistance of larvae reared on a natural host plant, trembling aspen (Populus tremuloides Michx.) was included as a diet treatment. Although trembling aspen foliage may be highly variable in nutrient concentration (e.g., $\mathrm{N}$ can range from $1.8-4.4 \% \mathrm{dw}$ within a single tree (Stockhoff, unpub. data)), the different leaves provided to larvae over time should tend towards a mean $\mathrm{N}$ concentration of $2-3 \% \mathrm{~N}(\mathrm{dw})$ and $56 \%$ available carbohydrate (Duke and Atchley 1986). Every two days, whole leaves were selected from the middle of a sprig and provided to larvae after disinfection in bleach (5.25\% sodium hypochlorite) for $5 \mathrm{~min}$ and rinsing in running distilled water. To reduce leaf desiccation, wet Kimwipes were wrapped around the leaf petiole, and humidity was maintained above $90 \%$

Larvac used in the respiration rate experiments were reared on one of two diets differing only in nitrogen concentration. Low and high nitrogen diets contained 4 and $32 \mathrm{~g}$ of casein/1, respectively, as before. Soluble starch concentration was kept constant at $20 \mathrm{~g} / 1$. Diets were otherwise prepared as above.

\section{Measurement of starvation resistance}

Upon hatching, 100-200 larvae from each of three egg masses were placed individually into $30-\mathrm{ml}$ rearing cups with environmental conditions as described above. Of these, twenty larvae received no food following hatching to assess starvation resistance of neonates. Remaining larvae were randomly assigned to one of the four diet treatments and fresh diet was provided every two days until initiation of the starvation treatment. Three other egg masses each provided an additional 150-250 larvae which were fed trembling aspen foliage prior to starvation. Final sample sizes were reduced from these initial numbers because of mortality prior to the starvation treatment and pupation of larvae during the starvation treatment.

To assess diet effects on survival of larvae without food, diet was removed from a subsample of larvae from each diet treatment. Larvae were chosen without regard to body size so as to avoid bias towards either fast- or slow-growing larvae. Individuals were weighed $24 \mathrm{~h}$ after food removal to ensure that most gut contents had been voided. Hydrated cellulose was placed at the bottom of each rearing cup to maintain approximately $75 \%$ relative humidity and to provide a water source for larvae. To assess the effect of body size on starvation resistance, larvae of different body masses were tested. To obtain these larvae, the food-removal process was begun on the second day after hatching, and repeated daily for new individuals as the cohort advanced to the ultimate instar (five instars for males, six for females). In total, 50, 46, 48, and 40 larvae were starved after rearing on the high nitrogen/high energy, low nitrogen/high energy, high nitrogen/low energy, and low nitrogen/low energy diets, respectively. A total of 209 aspen-fed larvae also were subject to the same starvation treatment.

Time to starvation was estimated as the time between food removal and death of the larva. Death was characterized by termination of visible signs of respiration (expansion and contraction of the cuticle), and lack of response to physical contact. In some cases, time of death could be observed directly. For most larvae, however, time had to be estimated. Because larvae gradually become inactive prior to death and rapidly dehydrate after expiring, time of death could be estimated with reasonable accuracy $( \pm 4 \mathrm{~h})$ based on pre-death observations of larval activity, and post-death degree of desiccation.

\section{Respiration rates}

Respiration rates were measured to determine the role of metabolic rate in larval resistance to starvation. It was hypothesized that shorter survival time when starved might be associated with higher 
absolute rates of utilization of energy stores, which should be reflected by elevated respiration rates. Rates were measured for both fed (free access to food) and starving (no access to food) larvae as it was unknown whether diet quality might affect larvae differently before and during starvation. Using environmental conditions as described before, larvae were reared to the fourth or fifth instar on $1.5 \%$ and $3.5 \%$ nitrogen diets with $20 \mathrm{~g} / \mathrm{l}$ of starch. Respiration rates were measured across two instars in order that larvae from the high and low nitrogen diet treatments would overlap in body mass, thus allowing body size to be used as a covariate in the statistical analysis. Respiration rates of 134 randomly chosen, fed larvae were taken approximately $30 \mathrm{~h}$ after molting to the fourth or fifth instar. Larvae at this stage are actively feeding, and had continuous access to a cube of artificial diet during respiration measurement. Respiration rates of diet and frass produced during respiration measurement were found to be negligible. Respiration rates of 224 starving larvae were measured $0.5-190 \mathrm{~h}$ after initiation of starvation, which was begun upon molting to the fourth or fifth instar. Respiration rates were measured across a range of time as it was not known how long after starvation was initiated that treatment effects, if any, might become apparent. Starving larvae were weighed upon conclusion of respiration rate measurement, while fed larvae were weighed $24 \mathrm{~h}$ later after gut contents were voided.

To obtain respiration rates, larvae were transferred to $30-\mathrm{ml}$ plastic cups containing $0.2 \mathrm{ml}$ of deionized distilled water and $0.2 \mathrm{ml}$ of $30 \%$ potassium hydroxide in separate vials. A $19 \times 5 \mathrm{~mm}$ strip of filter paper was placed in the $\mathrm{KOH}$ to increase the KOH-air interface. Cups were then immediately attached to the respirometer (Gilson Models GR14 and GR20). After a 15-30 min equilibration period, oxygen consumption was measured for $1 \mathrm{~h}$ at $25^{\circ} \mathrm{C}$. All gas volumes were corrected for the ambient barometric pressure prevailing at the beginning of each respiration trial.

Because respiration rates are potentially affected by larval activity, steps were taken to ensure that activity did not bias respiration results. To minimize effects of disturbance, larvae were not handled during the three $h$ immediately prior to a respiration trial. To assess differences in activity of larvae reared on $1.5 \%$ and $3.5 \% \mathrm{~N}$ diets, movement of starving larvae was observed every five min during the hour preceding measurement of respiration rate. The number of time periods in which the center of a larva moved $>1 \mathrm{~cm}$ was compared between high and low nitrogen treatments by a MannWhitney U test. Sample sizes were 59 and 55 for larvae reared on $1.5 \%$ and $3.5 \% \mathrm{~N}$ diets, respectively.

\section{Larval body composition}

To determine whether diet nitrogen and carbohydrate content affected larval body composition, chemical analysis was performed on both starved and unstarved fourth-instar larvae. Both starved and unstarved larvae were frozen, and guts were dissected out to avoid contamination by undigested food. All larvae were then oven-dried at $60^{\circ} \mathrm{C}$, ground under liquid nitrogen, and redried to constant mass. Chemical analysis was performed on 1-4 mg samples from individual larvae by a CHN Autoanalyzer (Perkin-Elmer model 2400). Percentage lipid, carbohydrate, and protein were estimated stoichiometrically from CHN values according to Gnaiger and Bitterlich (1984). Stoichiometric conversion requires estimation of larval ash-free dry weight and percentage non-proteinaceous nitrogen in larvae. Percentage ash was determined by ashing in a muffle furnace at $500^{\circ} \mathrm{C}$ for $4 \mathrm{~h}$. Non-proteinaceous nitrogen was assumed to reside largely in chitin, which contains $6.9 \%$ nitrogen and constitutes approximately $35 \%$ of the dry mass of the cuticle (Chapman 1982). Cuticle was found to comprise $7.8 \%$ of the larval dry mass. Proteinaceous nitrogen was calculated by subtracting non-proteinaceous nitrogen from total nitrogen.

In order to determine dry weight loss of larvae as a function of diet, subsamples of approximately 10 larvae from each diet treatment were dried at $60^{\circ} \mathrm{C}$ upon initiation of starvation and then weighed. Additional larvae were dried and weighed after death from starvation. So that weight loss could be compared across treatments, percentage dry mass losses of larvae in different diet treatments were corrected for initial treatment differences in percentage dry mass of pre-starved individuals.

\section{Statistical analysis}

Starvation data were analyzed by ANCOVA to determine the effects of nitrogen and energy on survival. Larval body mass $24 \mathrm{~h}$ after initiation of starvation was used as a covariate. Respiration data were similarly analyzed by ANCOVA, and by regression where slopes were unequal. Body composition data were analyzed by ANOVA and Mann-Whitney $U$ tests. The assumptions of homogeneity of variances (via Bartlett's test) and equality of slopes were tested as needed prior to analysis by ANOVA and ANCOVA.

\section{Results}

\section{Starvation resistance}

Unfed neonates had a survival time of $4.3 \pm 0.7 \mathrm{~d}$ (mean $\pm \mathrm{sd} ; \mathrm{n}=20$ ), with a minimum of $2.8 \mathrm{~d}$, and a maximum of $5.8 \mathrm{~d}$. This is similar to that reported by Capinera and Barbosa (1976) and DeGroff (1969) for gypsy moth. Because newly-hatched larvae typically remain on the egg mass for $24 \mathrm{~h}$ before silking to a new host plant, not all of this time is available for foraging. Larvae under natural conditions are subject to a myriad of environmental variables (e.g., fluctuating temperature, humidity), so that survival in the field may be more or less than $4 \mathrm{~d}$.

Starvation resistance of gypsy moth larvae was significantly associated with body mass prior to starvation and diet nitrogen concentration, but not with diet carbohydrate content (Table 1). Initial body mass was positively correlated with starvation resistance for both diet nitrogen concentrations and aspen (Fig. 1), so that within any one diet treatment, large larvae survived longer. Of several transforms attempted, the square root transform provided the best linear fit to the data. Food nitrogen concentration was negatively associated with starvation resistance; larvae reared on low nitrogen food survived nearly $3 \mathrm{~d}$ longer than larvae reared on high nitrogen food. Larvae reared on trembling aspen foliage had lower starvation resistance than larvae reared on either of the two artificial diets containing $1.5 \%$ or $3.5 \% \mathrm{~N}$. The slope of the regression line for aspen-fed larvae (provided in the legend of Fig. 1) is statistically identical to the slopes

Table 1. ANCOVA of survival of gypsy moth larvae following rearing on and subsequent removal of artificial diet differing in protein and starch concentrations. Initial dry mass prior to starvation was square root transformed to linearize the data

\begin{tabular}{lrrrr}
\hline Source & \multicolumn{1}{c}{ ss } & df & \multicolumn{1}{c}{ F } & \multicolumn{1}{c}{$\mathrm{p}$} \\
\hline Protein & 420.31 & 1 & 85.82 & $<0.001$ \\
Starch & 4.35 & 1 & 0.89 & 0.347 \\
Initial mass & 254.77 & 1 & 52.02 & $<0.001$ \\
Protein $\times$ starch & 10.11 & 1 & 2.06 & 0.152 \\
Error & 871.79 & 178 & & \\
\hline
\end{tabular}




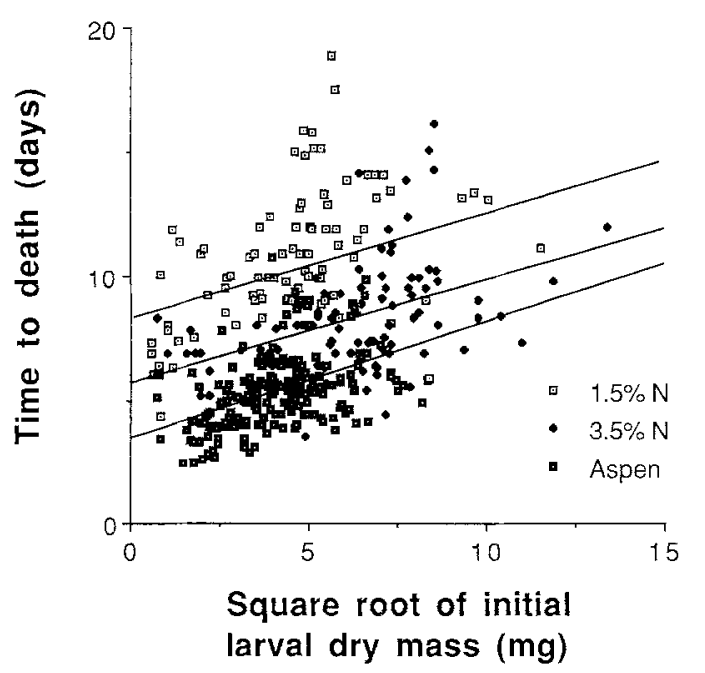

Fig. 1. Larval survival following food removal as a function of larval dry mass for gypsy moth larvae reared on artificial diet containing $1.5 \%$ or $3.5 \%$ nitrogen (dw). Values from low and high carbohydrate treatments are pooled within each diet nitrogen concentration. Regression equations are $y=8.319+0.493 x \quad(r=0.42)$ and $\mathrm{y}=5.648+0.418 \mathrm{x}(\mathrm{r}=0.46)$ for diets with $1.5 \% \mathrm{~N}$ and $3.5 \% \mathrm{~N}$, respectively. The regression equation for aspen-fed larvae is $y=3.39+0.473 x(r=0.46)$

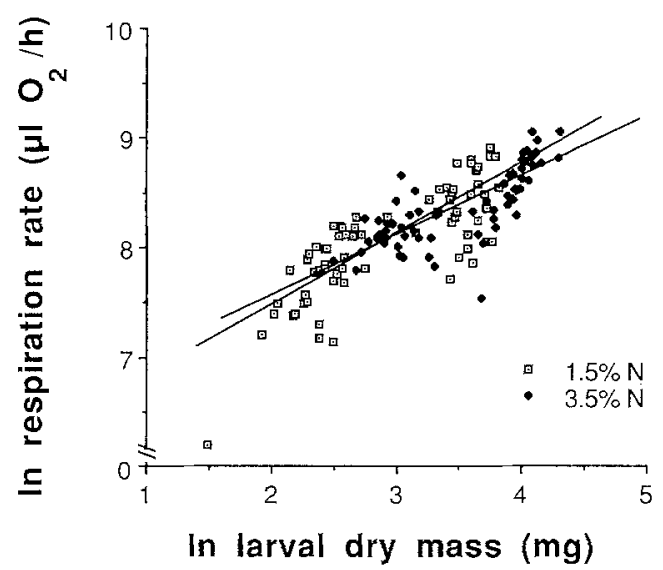

Fig. 2. Respiration rates as a function of larval dry mass for fed gypsy moth larvae reared on artificial diet with $1.5 \% \mathrm{~N}$ or $3.5 \% \mathrm{~N}$ $(\mathrm{dw})$. Regression equations for natural $\log$-transformed data are $y=6.18+0.635 x(r=0.79)$ and $y=6.54+0.520 x(r=0.77)$ for diets with $1.5 \% \mathrm{~N}$ and $3.5 \% \mathrm{~N}$, respectively

for larvae reared on $1.5 \%$ and $3.5 \% \mathrm{~N}$ artificial diet (approximate $\mathrm{t}$-test : $\mathrm{t}=0.150, \mathrm{df}=293, p>0.1 ; \mathrm{t}=0.529$, $\mathrm{df}=305, p>0.1$ for aspen vs $1.5 \% \mathrm{~N}$ and $3.5 \% \mathrm{~N}$, respectively), but the intercept for aspen-reared larvae is significantly lower than that for larvae reared on $1.5 \% \mathrm{~N}$ diet $(\mathrm{t}=7.54, \mathrm{df}=293, p<0.001)$ or $3.5 \% \mathrm{~N}$ diet $(\mathrm{t}=3.71$, $\mathrm{df}=305, p<0.001)$.

\section{Respiration rates}

Respiration rates of fourth- and fifth-instar larvae were not significantly different between larvae reared on $1.5 \%$ and $3.5 \%$ nitrogen diets for larvae with free access to

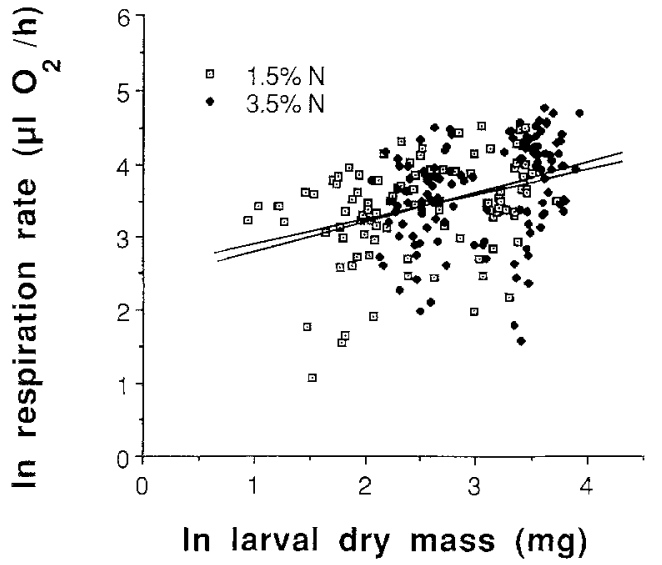

Fig. 3. Respiration rate as a function of larval dry mass for starving gypsy moth larvae reared on artificial diet containing $1.5 \% \mathrm{~N}$ or $3.5 \% \mathrm{~N}(\mathrm{dw})$. Multiple regression equations are provided in the text. Some of the residual scatter in respiration rate is due to time since food removal, which is represented by a third axis (not shown)

food (ANCOVA, $F_{1.131}=0.26, p>0.1$; Fig. 2). For starving larvae, analysis by ANCOVA was prevented by a significant interaction term between diet treatment $(1.5 \%$ and $3.5 \% \mathrm{~N})$ and the length of time after initiation of starvation that respiration rate was measured. Regression analysis was applied instead; multiple regression equations for natural log-transformed respiration rate $(\mathrm{y})$ and dry mass are $\mathrm{y}=2.635+0.312$ (mass) -0.0002 (time), and $y=2.951+0.370$ (mass) -0.006 (time) for $1.5 \% \mathrm{~N}$ and $3.5 \% \mathrm{~N}$ diets, respectively. Corresponding coefficients of correlation are 0.32 and 0.46 . The regression coefficients for time indicate that respiration rate declined with time since food removal for larvae reared on $3.5 \% \mathrm{~N}$ diet $(p<0.001)$ but did not change over the measurement period for larvae reared on the $1.5 \% \mathrm{~N}$ $\operatorname{diet}(p>0.1)$. Results of approximate t-tests indicate that the coefficients for larval mass and the intercepts are not significantly different between the $1.5 \%$ and $3.5 \% \mathrm{~N}$ treatments $(\mathrm{t}=0.42, \mathrm{df}=230, p>0.1 ; \mathrm{t}=0.72, \mathrm{~d} f=230$, $p>0.1$, respectively) (Fig. 3).

Because no strong difference was found in respiration rates between larvae reared on different diet nitrogen concentrations, values were pooled across diet treatments to compare respiration rates of unstarved and starving larvae. Unstarved larvae had approximately 2.5 times higher respiration rates than starved larvae (comparing Figs. 2 and 3). Pooling across nitrogen treatments, regression equations for natural log-transformed data are $\mathrm{y}=6.34+0.58 \mathrm{x}(\mathrm{r}=0.81)$ and $\mathrm{y}=2.53+0.35 \mathrm{x}(\mathrm{r}=0.34)$ for unstarved and starving larvae, respectively (where $y=\ln$ respiration rate and $x=\ln$ larval dry mass). The intercepts of these lines are significantly different $(t=17.17$, $\mathrm{df}=356, p<0.001)$ as are the slopes $(\mathrm{t}=3.05, \mathrm{df}=356$, $p<0.01$ ). The higher respiration rate of unstarved larvae is likely caused by a combination of greater movement and feeding activity, a higher level of energy metabolism associated with growth, and by the specific dynamic action of digestion (expenditure of energy in preparing products of digestion for entrance into metabolic pathways). 
Table 2. Percentage carbon (C), hydrogen $(\mathrm{H})$, nitrogen $(\mathrm{N})$, lipid, carbohydrate, and protein of unstarved and starved fourthinstar larvae reared on artificial diets differing in protein content. Means are provided with standard errors in parentheses. Comparisons are by Mann-Whitney $U$ tests, with $\alpha=0.05 / 6$ to adjust for multiple comparisons. Lipid, carbohydrate, and protein values do not sum to a constant percentage because of experimental error in $\mathrm{CHN}$ measurement

\begin{tabular}{|c|c|c|c|c|c|c|c|c|}
\hline \multirow[t]{2}{*}{$\begin{array}{l}\text { Larval } \\
\text { Condition }\end{array}$} & \multirow{2}{*}{$\begin{array}{l}\text { Diet } \\
\text { Percentage } \\
\text { Nitrogen }\end{array}$} & \multirow[t]{2}{*}{$\mathrm{n}$} & \multicolumn{3}{|c|}{ Percentage in larvae (dw) } & \multicolumn{3}{|c|}{$\begin{array}{l}\text { Percentage in } \\
\text { ash-free larval dw }\end{array}$} \\
\hline & & & $\mathrm{C}$ & $\mathrm{H}$ & $\mathrm{N}$ & Lipid & Carbo & Protein \\
\hline \multirow[t]{2}{*}{ Unstarved } & 1.5 & 16 & $\begin{array}{r}48.8^{\mathrm{a}} \\
(0.4)\end{array}$ & $\begin{array}{l}7.2^{\mathrm{a}} \\
(0.04)\end{array}$ & $\begin{array}{l}9.5^{\mathrm{a}} \\
(0.15)\end{array}$ & $\begin{array}{l}12.5^{\mathrm{a}} \\
(0.8)\end{array}$ & $\begin{array}{l}33.5^{\mathrm{a}} \\
(0.9)\end{array}$ & $\begin{array}{l}58.3^{\mathrm{a}} \\
(0.9)\end{array}$ \\
\hline & 3.5 & 12 & $\begin{array}{l}49.2^{\mathrm{a}} \\
(0.4)\end{array}$ & $\begin{array}{l}7.2^{\mathrm{a}} \\
(0.05)\end{array}$ & $\begin{array}{l}10.4^{\mathrm{b}} \\
(0.21)\end{array}$ & $\begin{array}{l}12.6^{\mathrm{a}} \\
(1.4)\end{array}$ & $\begin{array}{l}28.9^{\mathrm{b}} \\
(1.2)\end{array}$ & $\begin{array}{l}63.3^{\mathrm{b}} \\
(1.2)\end{array}$ \\
\hline \multirow[t]{2}{*}{ Starved } & 1.5 & 21 & $\begin{array}{l}42.7^{\mathrm{b}} \\
(0.3)\end{array}$ & $\begin{array}{c}6.1^{\mathrm{b}} \\
(0.04)\end{array}$ & $\begin{array}{l}13.1^{\mathrm{c}} \\
(0.16)\end{array}$ & $\begin{array}{r}0.0^{\mathrm{b}} \\
(0.0)\end{array}$ & $\begin{array}{l}16.5^{\mathfrak{c}} \\
(1.1)\end{array}$ & $\begin{array}{l}81.7^{\mathrm{c}} \\
(1.0)\end{array}$ \\
\hline & 3.5 & 20 & $\begin{array}{l}44.8^{\mathrm{c}} \\
(0.4)\end{array}$ & $\begin{array}{l}6.3^{\mathrm{c}} \\
(0.05)\end{array}$ & $\begin{array}{l}13.8^{\mathrm{d}} \\
(0.16)\end{array}$ & $\begin{array}{r}0.2^{\mathrm{b}} \\
(0.1)\end{array}$ & $\begin{array}{l}12.2^{\mathrm{d}} \\
(1.0)\end{array}$ & $\begin{array}{l}85.5^{\mathrm{d}} \\
(1.0)\end{array}$ \\
\hline
\end{tabular}

Movement of starving larvae was not different between larvae reared on $1.5 \% \mathrm{~N}$ and 3.5\% $\mathrm{N}$ diet (MannWhitney $\mathrm{U}=1528, p>0.1, \mathrm{n}=59,55$ for $1.5 \% \mathrm{~N}$ and $3.5 \% \mathrm{~N}$ diet, respectively).

\section{Larval body composition}

Percentage carbon $(\mathrm{C})$, hydrogen $(\mathrm{H})$, nitrogen $(\mathrm{N})$, lipid, carbohydrate, and protein in both unstarved and starved fourth-instar larvae were not affected by starch concentration of the diet (ANOVA using arcsine-transformed data; $\mathrm{df}=1,62, p>0.1$ for each component), so that values were pooled across carbohydrate treatments prior to comparison of nitrogen treatments. Lack of response is not for lack of appropriate carbohydrases because larvae appear able to digest soluble potato starch (Stockhoff, unpub. data). It is conceivable that both carbohydrate levels provided to larvae were in excess of larval needs, and future experiments will address this possibility.

Percentage $\mathrm{C}, \mathrm{H}, \mathrm{N}$, lipid, carbohydrate, and protein were all strongly affected by starvation (Table 2). Percentage $\mathrm{C}$ and $\mathrm{H}$ declined during starvation, while percentage $\mathrm{N}$ increased. Lipid and carbohydrate also declined during starvation, while percentage protein increased. Body nitrogen and protein content were significantly higher in larvae reared on high nitrogen diet, both in unstarved and starved larvae. Percentage $\mathrm{C}$ and $\mathrm{H}$ were not different between unstarved larvae reared on high and low nitrogen, but were significantly higher in starved larvae reared on high nitrogen diet. Percentage carbohydrate was lower in larvae reared on $3.5 \% \mathrm{~N}$ diet for both unstarved and starved larvae. Percentage lipid was not affected by diet nitrogen concentration in either unstarved or starved larvae.

According to Chossat's rule (Kleiber 1961), death occurs in starving organisms when body mass approaches $50 \%$ of the initial, unstarved mass. That rule was closely approximated by larvae in this experiment. Larvae had $55.3 \pm 0.9 \%$ (mean $\pm \mathrm{se} ; \mathrm{n}=118$ ) of their estimated prestarved dry mass at death.

\section{Discussion}

Results of these experiments indicate that diet, independent from body mass, is an important determinant of starvation resistance in gypsy moth larvae. Effects of diet on starvation resistance are likely mediated by body nutrient composition and not by changes in respiration rate. Although respiration rates declined more rapidly for starving larvae reared on $3.5 \%$ than on $1.5 \% \mathrm{~N}$ diet, this probably reflects the more rapid demise of larvae on the high nitrogen treatment. Because respiration rates were 1) statistically identical for unstarved larvae of equal mass, and 2) lower over time rather than higher for starving larvae reared on $3.5 \% \mathrm{~N}$ diet, the results do not support the hypothesis that shorter survival time by larvae reared on high nitrogen diet was caused by excessively high metabolic rates. Similar results were reported by Karowe and Martin (1989), who found that the respiration rate of Spodoptera eridania larvae was dependent upon the amino acid composition, but not the quantity, of ingested protein. Apparently, neither low nor high concentrations of dietary nitrogen impose a significant metabolic cost to gypsy moth larvae.

More rapid starvation of larvae reared on high nitrogen food is likely the consequence of depletion of smaller initial energy stores. This hypothesis is supported by the differences in body composition of larvae reared on the two nitrogen diets. Percentage lipid was initially identical, and lipid stores were virtually exhausted by starvation in all larvae (Table 2). The constancy of lipid stores despite changes in protein stores was unexpected, given the negative relationship between protein and lipid in some insects (Lii et al. 1975; Karowe and Martin 1989), and the generally (but not universally) positive relationship between starvation resistance and lipid reserves (Fast 1964). However, larvae reared on high nitrogen diets had greater fractions of their bodies as protein, and smaller carbohydrate reserves. Because carbohydrate is more readily utilized as an energy source than is protein, smaller carbohydrate reserves may have resulted in swifter mortality of larvae reared on high nitrogen diet. In further investigating this possibility, a comparison of the respiratory quotients $\left(\mathrm{RQ}\right.$, ratio of $\mathrm{O}_{2}$ to $\mathrm{CO}_{2}$ ) during starvation for larvae reared on low and high nitrogen diets would likely prove interesting. Because lipids, carbohydrates and proteins all differ in their $R Q$, the timing of shifts in the substrates used in energy metabolism could be detected and compared among starving larvae reared on different diets.

It is also possible that larvae on the high nitrogen diet suffered from disrupted ratios of stored nutrients (e.g., 
$\mathrm{C}: \mathrm{N}$ ratio), and that nutrient imbalance rather than nutrient deficiency per se led to lower starvation resistance. However, stress from nutrient imbalance would likely be manifest in reduced growth rate and/or altered metabolic rates of unstarved larvae, yet no such effects were detected. A direct test is needed to distinguish the roles of nutrient deficiency and nutrient imbalance in determining starvation resistance.

In the field, larvae that feed on host species or plants with different foliage nitrogen concentrations likely differ in their allocation towards carbohydrate and protein stores. As a result, larvae feeding on high nitrogen foliage may have smaller energy reserves and lower expected survivorship if starved than larvae feeding on low nitrogen foliage, despite identical body size. Because the ability of an individual to contribute genetic material to future generations is dependent upon the individual's survival to maturity, the expected fitness of an individual may vary according to the nitrogen concentration of the diet and the probability of starvation conditions.

Extrapolation of the results to field conditions should be done with caution, however. Aspen-reared larvae survived for a shorter time than larvae reared on either $1.5 \%$ or $3.5 \% \mathrm{~N}$ artificial diet, which suggests that diet nitrogen alone does not dictate survival under food stress. Although sibling group characteristics unrelated to diet treatment may have contributed to lower starvation resistance by aspen-fed larvae, a more likely explanation is that some aspect of the aspen foliage other than nitrogen concentration (approximately $2.5 \% \mathrm{~N}$ ) contributed to lower starvation resistance. The amino acid composition of foliar protein, for example, is different from that of the casein used in the artificial diets. Also, trembling aspen foliage contains the phenolic glycosides salicortin and tremulacin (Lindroth et al. 1987; Clausen et al. 1989), which may contribute to lower starvation resistance. Whatever the cause, the identical slopes of the starvation resistance vs body mass regressions for larvae reared on artificial diet and aspen indicates that the effect of the proposed aspen trait on larvae affects larvae of all sizes equally, and is not mitigated or strengthened by increasing larval mass.

This study refutes two generalizations evident in previously published studies concerning the relationships among fitness, body size, and growth. First, larger larvae are usually regarded as more fit because of potentially greater gamete production and larger nutrient stores for mating behavior, flight, etc. However, fitness is a function of survival to maturity. This study reveals that the relationship between body mass and the ability to survive to reproduce when larvae are food-stressed is mediated by diet and body composition. Larvae of identical body size (mass) can have substantially different expected fitnesses under conditions of food stress as a result of different diet histories. Likewise, larvae of very different body mass can have identical survival times. For gypsy moth, a larva reared on $1.5 \% \mathrm{~N}$ diet weighing only $20.25 \mathrm{mg}$ has the same expected survival time of $10 \mathrm{~d}$ as does a larva of $110.25 \mathrm{mg}$, nearly 5.5 times larger, but reared on $3.5 \% \mathrm{~N}$ diet (Fig. 1). Assuming larvae in a population starve for $10 \mathrm{~d}$, all larvae $>20.25 \mathrm{mg}$ that consumed low nitrogen food would be expected to survive. Larvae that consumed high nitrogen food would need to be $>110.25 \mathrm{mg}$ to survive the same period of food stress. Because larger body size does not guarantee greater survival to the age of reproduction, body mass does not translate directly into fitness in all situations.

Second, larvae with higher growth rates generally are regarded as more fit. This reasoning assumes that larvae which grow faster also grow larger over a set period of time, or are subject to predation/mortality risk for a shorter period of time, or both. Gypsy moth larvae grow up to $50 \%$ faster and larger on artificial diet containing $3.5 \% \mathrm{~N}$ than on $1.5 \% \mathrm{~N}$ (Stockhoff, unpub. data), a response which is typical of herbivorous insects. Larvae reared on high nitrogen diets had higher growth rates, but lower survival under conditions of food stress. This demonstrates that rapid growth cannot be assumed to lead to greater survival as there is a potential tradeoff between survival and growth.

A negative correlation between rapid growth rate and survival under starvation conditions suggests that there is no consistently strong directional selection towards high growth rate. If so, then larvae should not necessarily be expected to select or prefer foliage high in nitrogen, even if doing so would lead to more rapid growth rates. Growth rates of gypsy moth larvae can be quite variable, and a significant amount of this variation is often attributable to the egg mass from which a larva hatched (Rossiter 1987). This suggests at least a partial genetic basis to differences in growth rates. Individual and between-brood differences in growth rate components and host preference have been reported in other insects (e.g., Tabashnik et al. 1981; Rausher 1984; Jaenike 1985; Ng 1988), but the mechanisms which maintain this variability are difficult to identify. Ayres et al. (1987) hypothesized that between-brood differences in relative growth rate of Epirrita autumnata (Lepidoptera: Geometridae) were a consequence of different feeding behaviors and preferences with respect to food quality. It was proposed that larvae that are selective for leaves of high quality may grow best on high-quality trees, but become disadvantaged on low-quality trees because of excessive time spent searching. Consequently, the reduction in leaf quality that frequently follows insect outbreaks (Haukioja et al. 1987; Haukioja 1990) may favor non-selective genotypes and larvae that tolerate low-quality food, whereas more selective genotypes increase in frequency between outbreaks. Hence, provided leaf preference is a heritable trait, differences in foliage quality may exert disruptive selection such that recurrent periods of food stress maintain variability in the foraging behavior and preference of insect herbivores.

The results presented here for gypsy moth augment the general mechanism proposed by Ayres et al. (1987). Selective larvae that consume high quality foliage may be at a disadvantage during food stress not only because of excessive time spent searching, but because they have a lower probability of surviving the period of food stress. Data are lacking on the foraging behavior and preference of gypsy moth larvae of different genotypes, but evidence in support of the hypothesis is suggested by studies of 
Leucania separata Walker (Lepidoptera: Noctuidae) by Iwao $(1959,1962)$. Iwao found that the dark morph of $L$. separata which is common at high population density was more tolerant of unpalatable food than the lighter morph which is common at low population density. In addition, starvation resistance was significantly greater in the dark morph than in the light morph (Iwao 1962, 1967).

\section{Conclusion}

Two major conclusions may be drawn from the results of this study. First, diet composition strongly affects larval body composition. Larvae feeding on different hosts species or plants are likely to exhibit different nutrient allocation patterns in their tissues. Second, there is a potential tradeoff between growth achieved through consumption of high nitrogen food, and survival under food stress. Because of lower tolerance to food stress, large larvae with high growth rates are not necessarily more fit than small, slow-growing larvae. Large, rapidlygrowing larvae may be more fit when food is abundant, but this advantage diminishes when food is scarce. As a consequence, variability in food quality and abundance may promote the maintenance of diverse foraging behaviors and preferences among gypsy moth larvae. Finally, it should be stressed that the lab results are only suggestive of what may occur under field conditions. Field studies are needed that examine the relations among diet, body composition and survival in natural populations to corroborate results of the present lab study.

Acknowledgements. I thank L. Rankin for help in collecting the data, and G.E. Belovsky and M.M. Martin for helpful comments on early drafts of the paper. Two anonymous reviewers also provided criticisms that improved the manuscript. The work was supported by McIntire-Stennis Grant MICY-00078 to G.E. Belovsky and J.A. Witter, NSF Grant BSR-8904043 to M.M. Martin, and grants to the author by the Horace H. Rackham School of Graduate Studies. The work is in partial fulfillment of doctoral degree requirements at the University of Michigan.

\section{References}

Ayres MP, Suomela J, MacLean SF Jr (1987) Growth performance of Epirrita autumnata (Lepidoptera: Geometridae) on mountain birch: trees, broods, and tree $\times$ brood interactions. Oecologia $74: 450-457$

Capinera JL, Barbosa P (1976) Dispersal of first-instar gypsy moth larvae in relation to population quality. Oecologia 26:53-64

Chapman RF (1982) The insects: structure and function, 3rd ed. Harvard Univ Press, Cambridge

Clausen TP, Reichardt PB, Bryant JP, Werner RA, Post K, Frisby K (1989) Chemical model for short-term induction in quaking aspen (Populus tremuloides) foliage against herbivores. J Chem Ecol 15:2335-2346

Cymborowski B, Mieczyslawa B, Beckage NE, Williams CM, Riddiford LM (1982) Juvenile hormone titres and metabolism during starvation-induced supernumerary larval moulting of the tobacco hornworm, Manduca sexta L. J Insect Physiol 28: $129-135$

Dahlman DL (1973) Starvation of the tobacco hornworm, Manduca sexta. 1. Changes in hemolymph characteristics of 5thstage larvae. Ann Ent Soc Am 66:1023-1029
DeGroff BJ (1969) The influence of egg mass size on populations of the gypsy moth, Porthetria dispar (L.) (Lepidoptera: Lymantriidae). Unpub MS Thesis, State Univ NY, College of Forestry, Syracuse

Duke JA, Atchley AA (1986) Handbook of proximate analysis tables of higher plants. CRC Press, Boca Raton

Fast PG (1964) Insect lipids: a review. Mem Ent Soc Can 37:1-50

Gerber GH (1984) Effects of starvation in the first instar larvae on growth, development and survival in the red turnip beetle, Entomoscelis americana (Coleoptera: Chrysomelidae). Can Ent 116:529-536

Gnaiger E, Bitterlich G (1984) Proximate biochemical composition and caloric content calculated from elemental CHN analysis: a stoichiometric concept. Oecologia 62:289-298

Goulden CE, Hornig LL (1980) Population oscillations and energy reserves in planktonic Cladocera and their consequences to competition. Proc Nat Acad Sci 77:1716-1720

Haukioja E (1990) Induction of defenses in trees. Ann Rev Entomol $36: 25-42$

Haukioja E, Neuvonen S, Hanhimäki S, Niemelä P (1987) The autumnal moth in Fennoscandia. In: Berryman AA (ed) Dynamics of forest insect populations: patterns, causes, and management strategies. Plenum Press, New York

Hill L, Goldsworthy GJ (1970) The utilization of reserves during starvation of larvae of the migratory locust. Comp Biochem Physiol 36:61-70

Iwao S (1959) Phase variation in the armyworm, Leucania unipuncta Haeworth. IV. Phase difference in the range of food tolerance of the final instar larva. Jap J Appl Entomol and Zool $3: 164-171$

Iwao S (1962) Studies on the phase variation and related phenomena in some lepidopterous insects. Mem Coll Agric Kyoto Univ $84: 1-80$

Iwao S (1967) Resistance to starvation of pale and black larvae of the armyworm, Leucania separata Walker (Lepidoptera: Noctuidae). Botyu-Kagaku 32:44 46

Jaenike J (1985) Genetic and environmental determinants of food preference in Drosophila tripunctata. Evolution 39:362-369

Jalees S, Murad H (1974) Effect of starvation on the oxygen consumption in Laccotrephes maculatus Fabr. (Hemiptera: Nepidae). Indian J Ent 36:287-289

Karowe DN, Martin MM (1989) The effects of quantity and quality of diet nitrogen on the growth, efficiency of food utilization, nitrogen budget, and metabolic rate of fifth-instar Spodoptera eridania larvae (Lepidoptera: Noctuidae). J Insect Physiol 35:699-708

Kleiber M (1961) The fire of life: an introduction to animal energetics. Wiley, New York

Kopec S (1924) Studies on the influence of inanition on the development and the duration of life in insects. Biol Bull 46:1-21

Leonard DE (1970) Effects of starvation on behavior, number of larval instars, and developmental rate of Porthetria dispar. J Insect Physiol 16:25-31

Lii GY, Garlich JD, Rock GC (1975) Protein and energy utilization by the insect, Argyrotaenia velutinana (Walker), fed diets containing graded levels of an amino acid mixture. Comp Biochem Physiol 52A:615-618

Lindroth RL, Hsia MTS, Scriber JM (1987) Characterization of phenolic glycosides from quaking aspen. Biochem Syst Ecol $15: 677-680$

Lohr P, Gade G (1983) Carbohydrate metabolism in the stick insect, Carausius morosus. J Insect Physiol 29:287-293

Milstead JE (1967) Changes in weight and hemolymph total solids resulting from starvation in the sixth instar of Peridroma saucia and Pseudaletia unipuncta (Lepidoptera: Noctuidae). J Invert Pathol 10:306-312

Mwangi RW, Goldsworthy GJ (1977) Interrelationships between haemolymph lipid and carbohydrate during starvation in $\mathrm{LO}$ custa. J Insect Physiol 23: 1275-1280

$\mathrm{Ng} \mathrm{D}$ (1988) A novel level of interactions in plant-insect systems. Nature 334:611-613 
Odell TM, Butt CA, Bridgeforth AW (1985) Lymantria dispar. In: Singh P, Moore RF (eds) Handbook of insect rearing, vol 2. Elsevier, New York

Pearl R, Parker SL (1924) Experimental studies on the duration of life. X. The duration of life of Drosophila melanogaster in the complete absence of food. Am Nat 58:193-218

Peters RH (1983) The ecological implications of body size. Cambridge Univ Press, New York

Rausher MD (1984) Tradeoffs in performance on different hosts: evidence from within- and between-site variation in the beetle Deloyala guttata. Evolution 38:582-595

Rossiter MC (1987) Genetic and phenotypic variation in diet breadth in a generalist herbivore. Evol Ecol 1:272-282

Saleem MA, Shakoori AR (1985) Starvation and refeeding in Tribolium castaneum (Herbst). I. Effect on some biochemical components of sixth instar larvae. Can J Zool 64:1628-1632

Schroeder LA (1976) Effect of food deprivation on the efficiency of utilization of dry matter, energy, and nitrogen by larvae of the cherry scallop moth Calocalpe undulata. Ann Ent Soc Am $69: 55-58$
Siegert KJ (1987) Carbohydrate metabolism in starved fifth instar larvae of Manduca sexta. Arch Insect Biochem Physiol $4: 151-160$

Siegert KJ (1988) Hormonal regulation of fat body glycogen phosphorylase activity in larval Manduca sexta during starvation. Gen Compar Endocr 71:205-211

Siegert K, Ziegler R (1983) A hormone from the corpora cardiaca controls fat body glycogen phosphorylase during starvation in tobacco hornworm larvae. Nature 301:526-527

Singhal RN, Vats LK (1976) Effect of starvation on food consumption, assimilation, respiration and ecological efficiencies in adult Poecilocerus pictus Fabr. Indian J Ent 38:351-356

Tabashnik BE, Wheelock H, Rainbolt JD, Watt WB (1981) Individual variation in oviposition preference in the butterfly, Colias eurytheme. Oecologia $50: 225-230$

Threlkeld ST (1976) Starvation and the size structure of zooplankton communities. Freshwater Biol 6:489-496

Woodring JP (1984) The effects of starving versus fasting on blood composition in larval house crickets. J Insect Physiol $30: 251-255$ 